\title{
International Currencies Past, Present and Future: Two Views from Economic History
}

\author{
Barry Eichengreen*
}

The views expressed herein are those of authors and do not necessarily reflect the official views of the Bank of Korea. When reporting or citing this paper, the authors' name should always be explicitly stated.

* Professor, University of California, Berkeley

This is a revision and extension of a presentation to the Fourth Latin American Congress in Economic History, Bogota, July 2014. I am grateful to my coauthors Marc Flandreau, Arnaud Mehl and Livia Chitu, on whose collaboration I draw here, as noted below, and to the Clausen Center at UC Berkeley and the Bank of Korea for financial support. Colleagues at the Bank of Korea provided guidance on this revision. 


\section{Contents}

I . International Currencies Past, Present and Future:

Two Views from Economic History ……………………………. 1

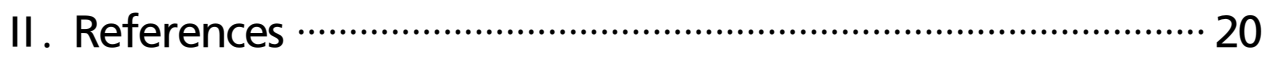




\section{International Currencies Past, Present and Future: Two Views from Economic History}

This paper contrasts two views of international currency status: an "old view" in which network increasing returns are sufficiently strong that one currency dominates international markets at any point in time, versus a "new view" in which networks are open and several international currencies can coexist. It marshals historical evidence in favor of the "new view" and suggests that several national currencies, most plausibly the U.S. dollar and Chinese renminbi, are likely to share this international currency role in the not-too-distant future. 
The history of the international economy is regularly told through the lens of the rise and fall of the great powers. Angus Maddison (1982) characterized the dynamics of global growth in terms of the gap between the economic leaders and economic followers and the moving technological frontier defined by the achievements of a rotating cast of leading economic powers. Charles Kindleberger described global dynamics in terms of the changing identity but unchanging importance of the lead economy, which in his analysis plays a key role in stabilizing the international system (see Kindleberger 1973, 1988). These stories are told in terms of British hegemony in the 19th century (emphasizing the imperialism of free trade, which made available essential supplies of cheap cotton and opened foreign markets to exports of British manufactures, rendering Britain the leading trading and exporting nation as late as 1913), followed by U.S. hegemony in the 20th century (courtesy of what is sometimes referred to as the Bretton WoodsGATT system) and (extrapolating) Chinese hegemony in the 21st.

Sometimes this same story is told thr ough the lens of currencies (see for example Williamson 2012). The 19th century international economy - the first age of globalization and the era of the international gold standard - was dominated by the pound sterling. This was when the Bank of England served as "conductor of the international orchestra," as John Maynard Keynes put it (Keynes 1930). Britain's role as the leading foreign lender and home to the world's most liquid financial market gave its central bank singular leverage over the international monetary system. The country's control of colonial trade, trade with India in particular, smoothed the adjustment of its balance of payments and allowed the Bank to stabilize the operation as the system at low cost (a recent treatment is de Cecco 2009).

The 20th century international economy - or at least the international economy of the second half of the century, following a turbulent and unsettled first half was then organized around the dollar and dominated by the United States. The dollar played a distinctive role in the post-World War II Bretton Woods System, under which the greenback was pegged to gold but other currencies were pegged to the dollar, either de facto or de jure. With only the United States possessing deep and liquid financial markets open to the rest of the world, the dollar was the 
dominant international and reserve currency. This gave the Federal Reserve System leverage over global financial conditions - leverage that persists today, as reflected in complaints from policy makers in emerging markets about, equally, U.S. quantitative easing and monetary tightening, or "tapering").1) The influential international monetary economists Milton Gilbert and Ronald McKinnon refer to the monetary arrangements of the period, revealingly, not as the Bretton Woods and post- Bretton Woods Systems but as the "gold-dollar system" and the "dollar standard" (see Gilbert 1968 and McKinnon 1996, 2010).

Extrapolating into the future, it is suggested that the global economy of the 21st century will be organized around the currency of China, the largest national economy, and regulated by its central bank. China is poised to overtake the United States as the largest economy, much as the U.S. overtook Britain in the late 19th century. It follows that for the same reasons the dollar overtook sterling as the dominant international currency, the renminbi is poised to overtake the dollar. Or so it is argued. In particular, it is argued by Arvind Subramanian of the Peterson Institute of International Economics, who has advanced the case in a series of provocative books and articles (Subramanian 2010, Subramanian and Kessler 2013). Those who see China as the emerging economic superpower more in Asia than globally similarly anticipate that the renminbi will dominate mainly in that part of the world (Park and Song 2011). Others who question this scenario of American economic decline and Chinese dominance similarly question whether the dollar will be superseded by the renminbi (see e.g. James 2009a, Prasad 2014).

This view, that economic dominance and monetary-cum-financial dominance go hand, has a basis in history (see also Cohen 2013; Flandreau and Jobst 2009; Cohen and Benney 2011). It also has a basis in theory. It flows from models in which network externalities are powerful and first-mover advantage matters importantly (see e.g. Krugman 1980,1984; Matsuyama, Kiyotaki and Matsui 1993; and Rey 2001). The currency of the country that has, historically, been the leading commercial and financial power is the natural first mover, has the largest installed base, and enjoys an intrinsic comparative advantage. When network increasingly

1) My own discussion is in Eichengreen (2013a). 
returns are sufficiently strong, it follows that international currency status is a natural monopoly. When such increasing returns are strong, in other words, there is room for only one consequential global currency, namely that of the dominant economy. In the past it was sterling. Now it is in the dollar. And in the future it will be the renminbi.

How long in the future is a separate question. Models featuring strong network effects can also be models in which persistence is strong. ${ }^{2)}$ Historically, a very large shock (a world war, for example) has been required to displace it. It follows that a national currency can retain its international role even after the issuer has lost its economic, fiscal and political dominance, just as sterling hung on for decades after the U.S. surpassed Britain in sheer economic size in the 1870s and as the leading commercial and financial power in the 1910s.

But this also means that an international currency can retain its dominance even after the issuer has lost the economic, fiscal and political capacity to provide international currency services on the scale required by the expanding global economy. The results can be awkward. De Cecco (1974) emphasized the relative economic decline of Britain before 1913 in conjunction with the continued dependence of the world economy on a sterling-centered system as a factor in the financial tensions and economic instability in the period leading up to World War I. Others, similarly, attribute global imbalances at the turn of the early 21 st century and even the global financial crisis that followed soon thereafter to the world's dependence for international liquidity on a United States that accounted for a declining share of an expanding global economy and therefore with a declining capacity to provide safe and liquid assets on the requisite scale (for balanced appraisals see Whelan 2010, Borio and Disyatat and Obstfeld and Rogoff 2011). This is one way of understanding the chronic fragility of the international monetary system, a phenomenon that has long occupied economic historians and troubled policy makers.

While compelling, this view is based on a limited empirical foundation. We know something about the currency composition of foreign exchange reserves in

2) The earliest and still most influential formalization of the point is Arthur (1989). See, however, footnote 17 below. 
the decade leading up to World War I, courtesy of Lindert (1969). We then may know something about it in the period starting in the early 1970s, courtesy of the IMF and its Currency Composition of Official Foreign Exchange Reserves (COFER) data base.3) But we know, or until recently have known, strikingly little about the period in between, from the 1920s through the 1960s.

In this survey I will attempt to at least partially correct this deficiency. ${ }^{4)}$ In doing so, I challenge the conventional wisdom as I characterize it above. I argue for replacing the traditional (or "old") view of international currencies with a "new" view with very different theoretical foundations and empirical implications. The new view builds on a literature on standards that emphasizes open systems. It builds on work in which even high switching costs can be overcome by effective coordination mechanisms and/or large shocks. See for example Farrell and Klemperer (2007), David and Bunn (1988), and Clark (2003). For a distinct but related view see Liebowitz and Margolis (1995).5)

Where the old view emphasized network effects, the new view emphasizes open systems, as just noted. Where the old view placed great weight on network effects, first-mover advantage and lock-in, the new view posits that interchangeability costs are not that high and first-mover advantage can be overcome relatively quickly. Where the old view suggested that network increasing returns are so strong that only one true global currency can exist at a point in time, the new view suggests that increasing returns are not so strong as to rule out the existence of multiple international currencies at a point in time.6) Where the old view found support in the dollar's dominance in the second half of the 20th century, the new view finds support in other periods during which several currencies have simultaneously

3) Even the COFER data base is imperfect, since some countries, notably China, do not report the currency composition of their international reserves to the IMF. On the COFER data base, see http://www.imf.org/ external/np/sta/cofer/eng/ .

4) In particular, I will report on a project in which I have been engaged (together with collaborators including Marc Flandreau, Arnaud Mehl and Livia Chitu) that seeks to fill in the missing middle, providing more information on international currencies in the 20th century, and especially in the under-documented era prior to 1970 .

5) The term "new view" of international currency competition was first used by Frankel (2011).

6) In their calibrated model of international currency status, Portes and Rey (1998) show that a mixed equilibrium (i.e. multiple international currencies) is possible despite network externalities. 
played consequential international roles. Where the old view implied that the dollar's dominance might persist for an extended period, the new view predicts that the dollar will have rivals sooner rather than later. That supposes, of course, that the potential rivals get their acts together, an observation which will lead me at the end to make some brief remarks about the euro and the renminbi.

Systematic historical evidence starts, as noted, with Lindert's estimates of the currency composition of foreign exchange reserves in 1899 and 1913. This is the period when the practice of holding foreign exchange reserves first rose to prominence. The late 19th century saw rapid growth of international borrowing and lending (Obstfeld and Taylor 2005), where it was often governments on the borrowing end of the transaction. Governments warehoused their foreign-currency -denominated borrowings in the financial center where they borrowed, whether for convenience or to reassure their lenders. They held foreign balances to insure against interruptions to the flow of foreign loans. They adjusted those balances to insulate the domestic economy from volatility created by fluctuations in international capital flows. The growth of international financial transactions and the associated market liquidity, together with the stability conferred by the gold standard, rendered foreign currency balances an attractive alternative, or more precisely, supplement to gold as backing for the domestic circulation.7) Correspondingly, countries like Austria, Russia and Japan adapted their gold-standard practices to make it possible for their central banks to hold this attractive and remunerative form of backing. 8) $^{2}$

Lindert seeks to quantify the practice by drawing on the published balance sheets of treasuries, central banks, and other banks of issue. In some cases he makes use of ancillary evidence on the location and currency in which reserves were held. Aggregating across countries, he produces the results in Figures 1 and 2. The precision of the estimates can be questioned, as always, but not the overall

7) Eichengreen and Flandreau (2014) discuss the role of the gold standard and the growth of foreign lending in encouraging the practice. Flandreau and Ugolini (2013) argue that the Overend, Gurney crisis in 1866 and the government's constructive response were the key events that solidified investors' expectations of market liquidity, in London in particular, encouraging the development of the new key currency system.

8) Austria-Hungary, to be precise. 
Figure 1. Shares of Currencies in Known Reserves, 1899

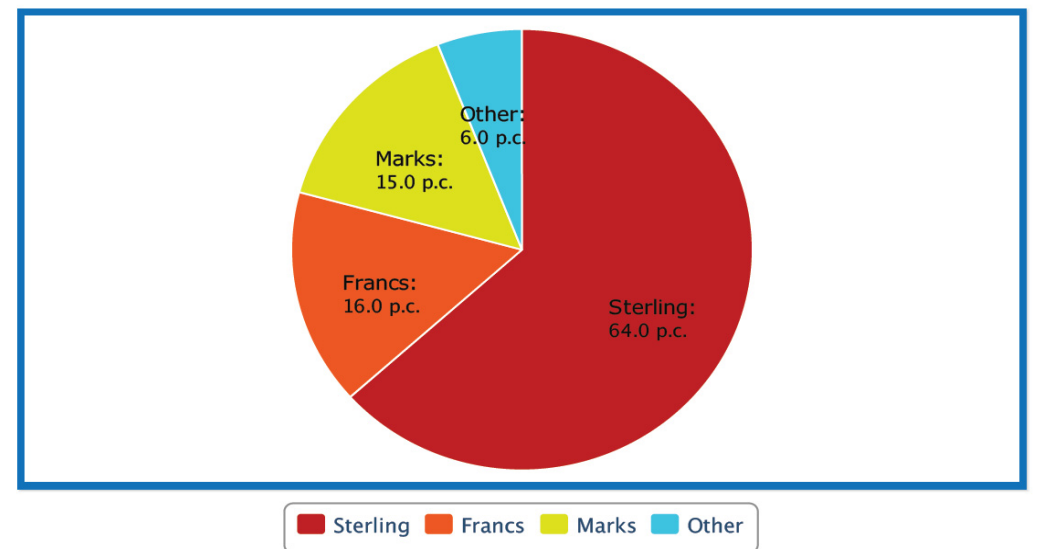

Source: Lindert (1969)

Figure 2. Shares of Currencies in Known Reserves, 1913

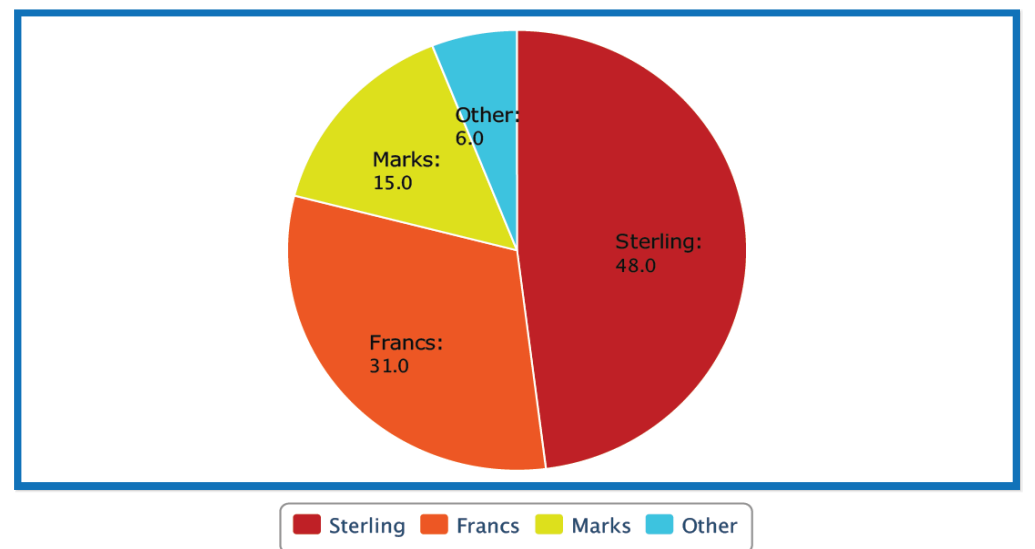

Source: Lindert (1969)

picture, which is inconsistent with the natural monopoly view. We see how, circa 1899 sterling accounted for the majority of identified foreign exchange reserves, but French francs, German marks and other miscellaneous currencies (Swiss francs, Dutch guilder) accounted for nonnegligible shares of the total. If anything, sterling's dominance declines over the subsequent decade and a half, with gains mainly taking the form of French francs, which are accumulated by Russia and other countries. 
Some will be inclined to dismiss this evidence on the grounds that foreign exchange reserves played a limited role before 1913, when they accounted for perhaps just 10 per cent of the reserves of central banks and governments. But this was no longer true in the 1920s. Governments sought to actively encourage the practice of supplementing gold with foreign exchange, first at the Brussels Conference in 1920 and then in Genoa in 1922. Price levels had risen sharply during World War I, and pushing them down now, in politically acceptable fashion, was easier said than done. Given the relative inelasticity of gold supplies, the specter of a global gold shortage therefore loomed (Eichengreen and Flandreau 2009).

At Genoa, in particular, leaders sketched the outlines of an international gold-exchange standard based on regularization of the ad hoc practices of prewar years. Resolution 9 of the report of the Financial Commission to the Genoa Conference declared that the aim of the convention was to "centralize and coordinate the demand for gold, and so avoid those wide fluctuations in the purchasing power of gold which might otherwise result from the simultaneous and competitive efforts of a number of countries to secure metallic reserves." Resolution 11 stated that the "maintenance of the currency at its constant gold value must be assured by the provision of an adequate gold reserve of approved assets, not necessarily gold."9)

Creating this system entailed codifying previous ad hoc practices - altering central bank statutes, or creatively drafting new statutes specifying the types and amounts of foreign exchange that might be held in cases where central banks had not existed previously. The League of Nations was enlisted in the cause (a recent treatment of the role of the League is Decorzant and Flores 2012). In Austria, Danzig, Hungary, Bulgaria, Estonia and Greece, League of Nations stabilization programs included the creation or reorganization of central banks, which were endowed with statutes authorizing them to hold foreign exchange as a component of their reserves.

By 1928, the heyday of the interwar gold-exchange standard, the share of foreign exchange in the combined gold and foreign exchange reserves of 28 European

9) Nurkse (1944), p. 28. 
Figure 3. Global Foreign Exchange Reserves, 1929
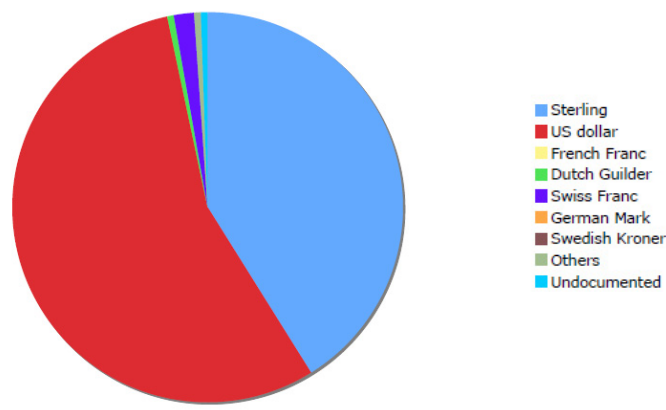

Source: Eichengreen and Flandreau (2009)

countries was fully 42 per cent. Some countries (Austria, Sweden, Finland, Portugal, Latvia, Estonia, Lithuania, Czechoslovakia, Albania and, beyond Europe, Ecuador, Chile and India) now held the majority of their reserves in this form.

This much is known from the published balance sheets of central banks, as tabulated by the League of Nations. ${ }^{10)}$ But what do we know about the currency composition of those foreign exchange reserves? The answer, until recently, was quite little. Robert Triffin once published estimates showed sterling as far-and-away the dominant reserve currency on the eve of World War II (Triffin 1960). But how we came up with those estimates is unclear.

More recently, Flandreau and Eichengreen assembled evidence on this question from the unpublished balance sheet of central banks. Figure 3, from Eichengreen and Flandreau (2009), shows estimates of the currency composition of global foreign exchange reserves in 1929. Reserves are split more or less evenly between the dollar and sterling. As will be clear, the historical evidence for this period is not obviously consistent with the "old" or "natural monopoly" view, in other words. It also throws doubt on the presumption that persistence is overwhelmingly strong when it comes to the currency composition of reserves, and on the claim that the dollar only overtook sterling only after World War II, as much as half a century after the U.S. surpassed Britain as the leading trading and lending nation.

Reserve currency status is only one aspect of international currency status, of

10) See inter alia League of Nations (1937). 
Figure 4. Dollar and sterling acceptances 1927-37

In millinons of pounds sterling

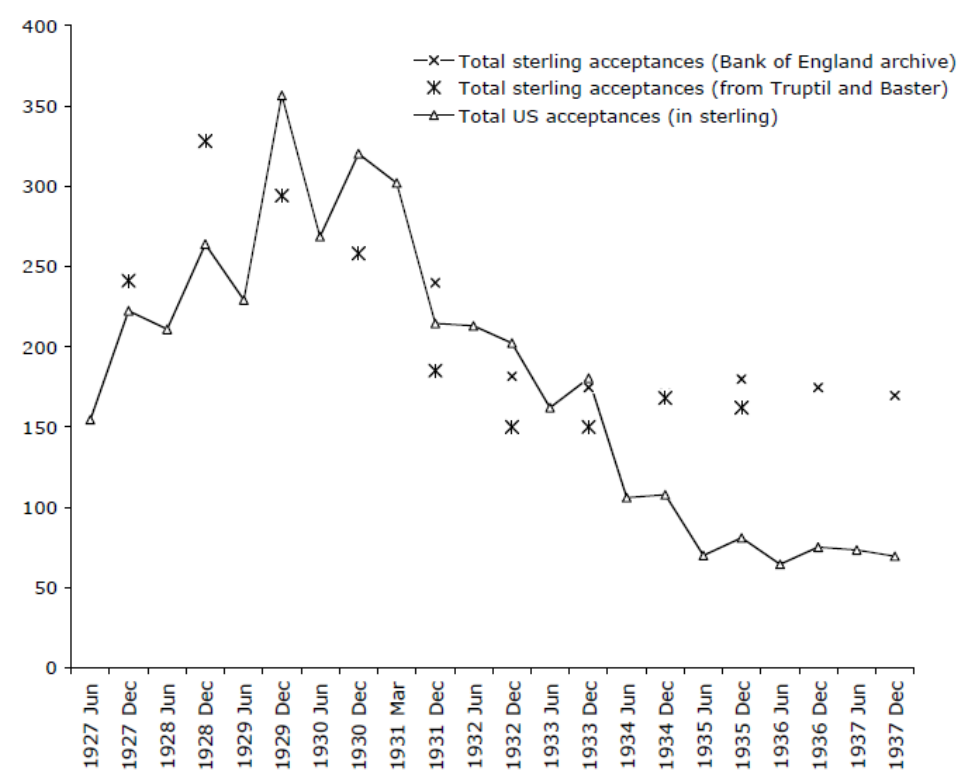

Source: Eichengreen and Flandreau (2012)

course. But more support for the new view can be gleaned from evidence on various other aspects. Eichengreen and Flandreau (2012) consider the use of currencies as a source of trade credit and means of payment in the 1920s and 1930s. As shown in Figure 4, sterling and the dollar were of roughly equal importance in this domain already in the 1920s. As in the case of reserves, the dollar surpassed sterling, if slightly, by the late 1920s, although it gave back its lead in the 1930s.

The same is again true, Chitu, Eichengreen and Mehl (2012) establish, of the use of currencies for denominating foreign bonds. As shown in Figure 5, use of the dollar to denominate foreign bonds was essentially nonexistent prior to World War I, a situation that then changed quickly. By the early 1920s, the dollar and sterling shared this international function, like others, more or less equally. The dollar then surpassed sterling as a currency of denomination for international bonds in the late 1920s, the heyday of U.S. foreign lending. ${ }^{11)}$ Interestingly, this is one domain where sterling did not regain the ground lost previously in the 1930s, presumably 


\section{Figure 5. Global Foreign Public Debt (excluding Commonwealth Countries), as Shares of Total}

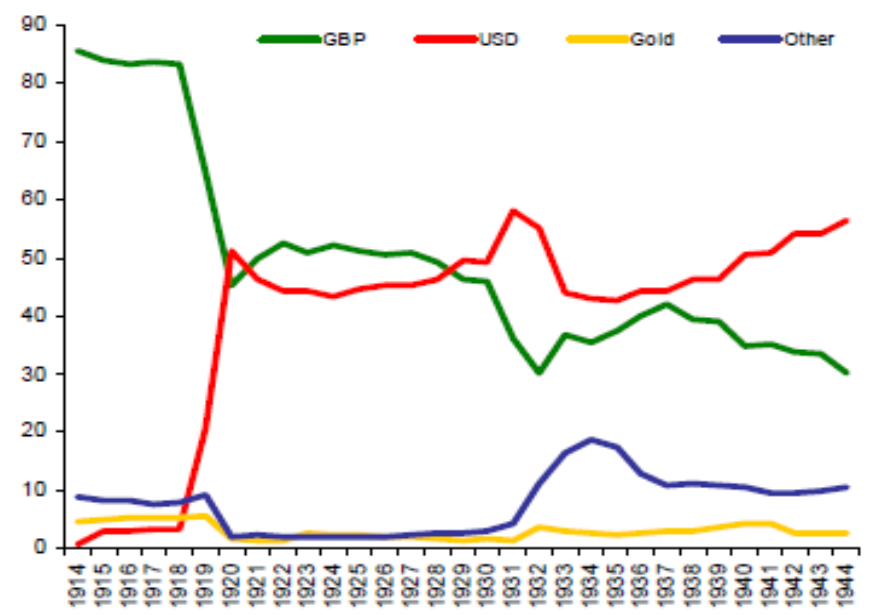

Source: Chitu, Eichengreen and Mehl (2012)

reflecting the maintenance of informal controls on foreign lending by the British government.

Finally, we can consider the currency denomination of transactions in global oil markets. This is another domain for which it is argued, on the basis of recent experience, that network increasingly returns are strong and a single currency tends to dominate. We have evidence on this question for the 1930s, 1940s and 1950s for European countries, presented by Eichengreen, Chitu and Mehl (2014a). ${ }^{12)}$ As depicted in Figure 6, this shows, once again, that payment for oil imports was made, in more or less equal amounts, in dollar and nondollar currencies, where nondollar means, essentially, sterling. It can be argued that the

11) Adding Commonwealth countries to the sample of countries shown in Figure 5, in particular Australia, Canada, India, New Zealand and South Africa (all of which were titled towards sterling issuance largely due to their political ties with the U.K.) confirms that there was room for more than one international financial currency then: by 1931, the share of the dollar (45 per cent) was almost equal to that of sterling (51 per cent).

12) The data they utilize were gathered by statisticians employed by the Organization for European Economic Cooperation (OEEC, the predecessor to today's OECD) on the basis of submissions by 16 European countries participating in the European Recovery Program (recipients of Marshall Plan aid). See ECA (1949). 
Figure 6. Currency Denomination of Oil Imports, 16 European Countries (per cent of total)

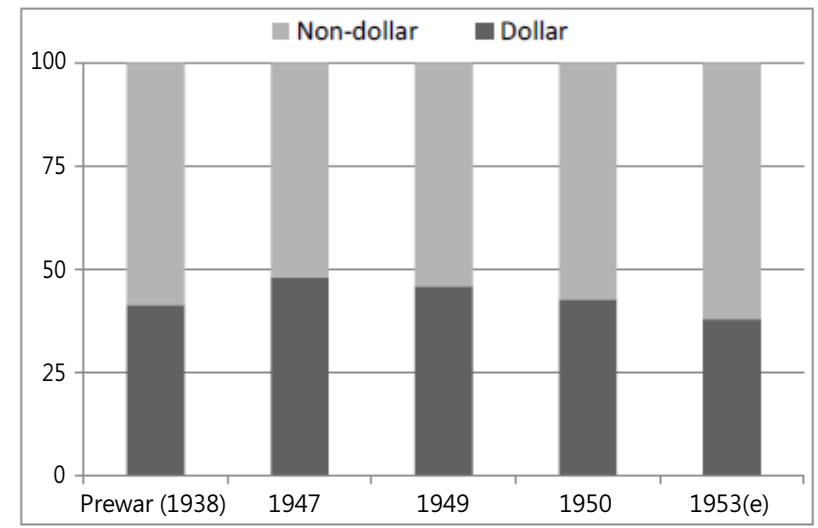

Source: Eichengreen, Chitu and Mehl (2014a)

late 1940s and early 1950s, the era of the dollar shortage, was special. But it is revealing that exactly the same pattern is evident in 1938, when a dollar shortage analogous to that of the post-World War II period did not prevail.

These observations of how the dollar had come to rival and, in some cases, surpass sterling as an international and reserve currency already in the 1930s, undermining the case that international currency status is a natural monopoly, raise the troubling question of why these facts were not appreciated previously. One answer is that much of the ground the dollar gained as an international currency status is a natural monopoly, raise the troubling question of why these facts were not appreciated previously. One answer is that much of the ground the dollar gained as an international and reserve currency in the 1920s it then lost in the unstable 1930s, as central banks liquidated their foreign exchange reserves, and their dollar reserves in particular. For a subset of countries, Eichengreen and Flandreau (2009) have a continuous run of reserve holdings by currency. As shown in Figure 7, these underscore the speed of the dollar's rise in the 1920s but also the disproportionate liquidation of dollar reserves in the 1930s. Figure 8, for a larger sample of central banks, includes only selected years but suggests the same pattern. 
Figure 7. Currency Composition of Reserves, Continuous Estimates for Four Countries

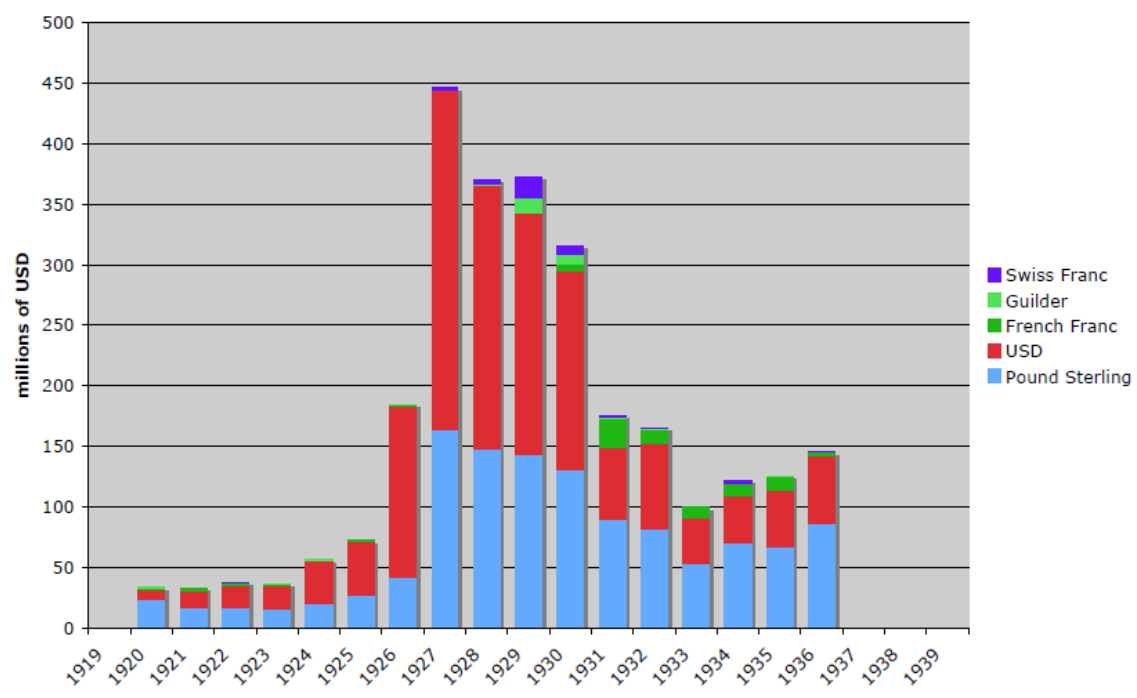

Source: Eichengreen and Flandreau (2009)

Figure 8. Currency Composition of Reserves, Ten Countries

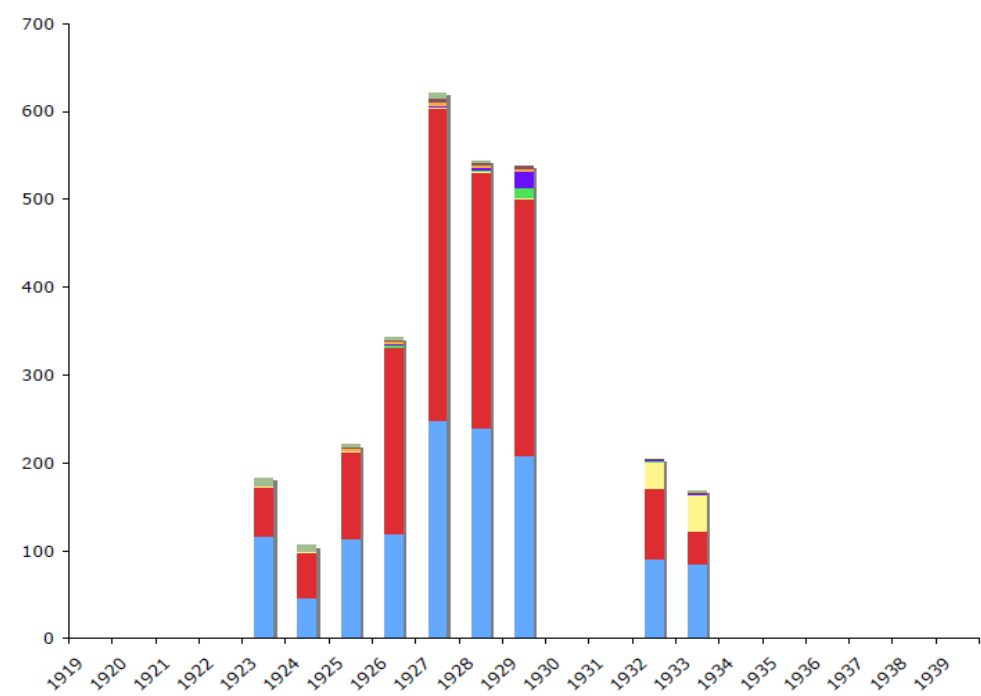

Source: Eichengreen and Flandreau (2009) 
Figure 9. Currency Composition of Reserves, Scandinavian Countries

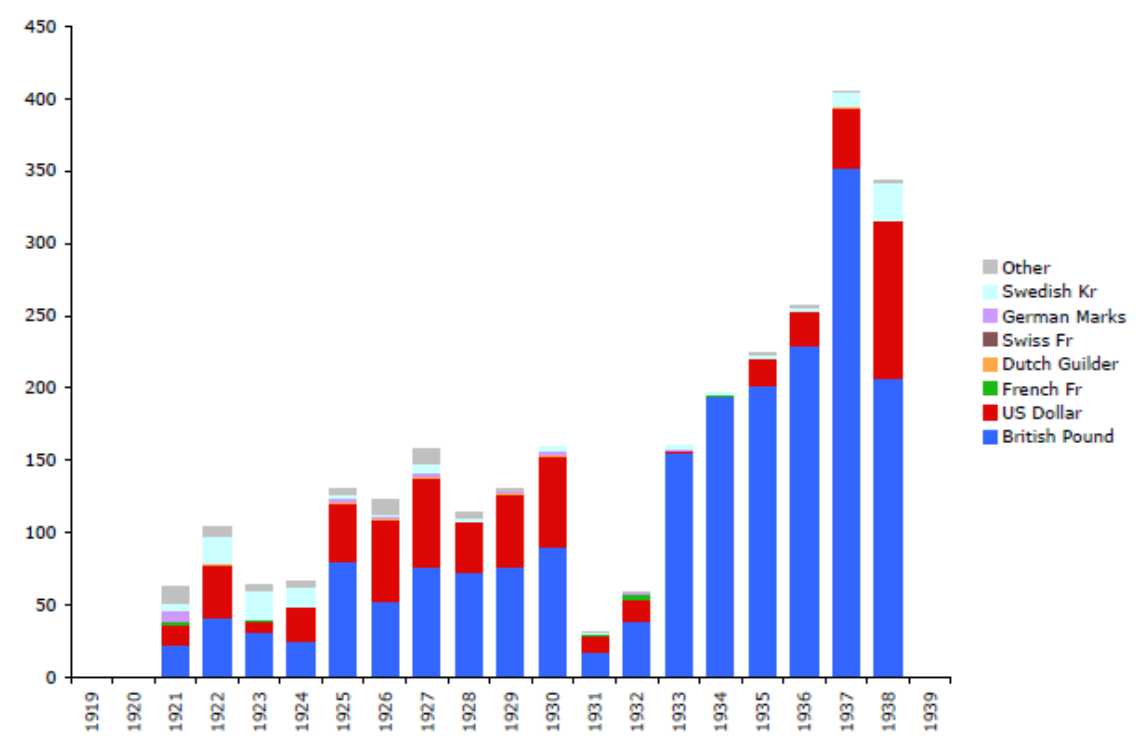

Source: Eichengreen and Flandreau (1999)

Another feature of the period is the regionalization of foreign exchange holdings (see Nurkse 1944 and James 2009b). Sterling remained more popular in the Sterling Area (hence the name), whose members pegged their currencies to the pound or at least shadowed it. In contrast, dollar reserves dominated across much of Latin America. Figure 9 shows the case of the Scandinavian countries, which move from diversified reserve portfolios in the 1930s to sterling dominated portfolios in the 1930s, and finally back into dollar, at least to a limited extent, in the late 1930s when war clouds begin to gather over Europe.

What then happened after World War II? Although evidence from the international oil market, noted above, provides a hint, the picture remains opaque. Typically, analyses start in the 1970s, when the IMF's COFER data become available. They then end around 1999, with the advent of the euro (see e.g. Chinn and Frankel 2005).

Using sources like Horsefield (1969) and the IMF's annual reports, it is possible however to do better. On this basis, Eichengreen, Chitu and Mehl (2014b) reconstruct the complete time series of global foreign exchange reserves, by currency, from 
1947 to the present, as shown in Figure 10.13) A striking feature of the figure is the dominance of the British pound in the aftermath of World War II, when it accounted for more than 80 per cent of foreign exchange reserves. This is then followed by a sharp reversal of fortune, with the dollar overtaking sterling and accounting for more than 50 per cent of identified foreign exchange reserves by the early 1950s. From there, the dollar's rise continues unabated through the mid1970s. ${ }^{14)}$ Sterling's decline as a share of global reserves similarly continues unabated and reaches its current levels in the low single digits at around the same time.

From the early 1970s one then observes the rise of the deutschemark and the euro as international reserves. Taken together, the lines representing these currencies trend steadily upward until the onset of the euro area sovereign debt crisis in 2009. One also sees the rise and fall of the Japanese yen, whose share in global reserves peaks in the late 1980s and early 1990s, coincident with the end of the "bubble economy" and the onset of the Japanese economic and financial crisis, along with the rise of various subsidiary reserve currencies (on the yen see Frankel 2012 and Kwan 2012).

Figure 10. Currency Composition of Foreign Exchange Reserves, 1947-2013

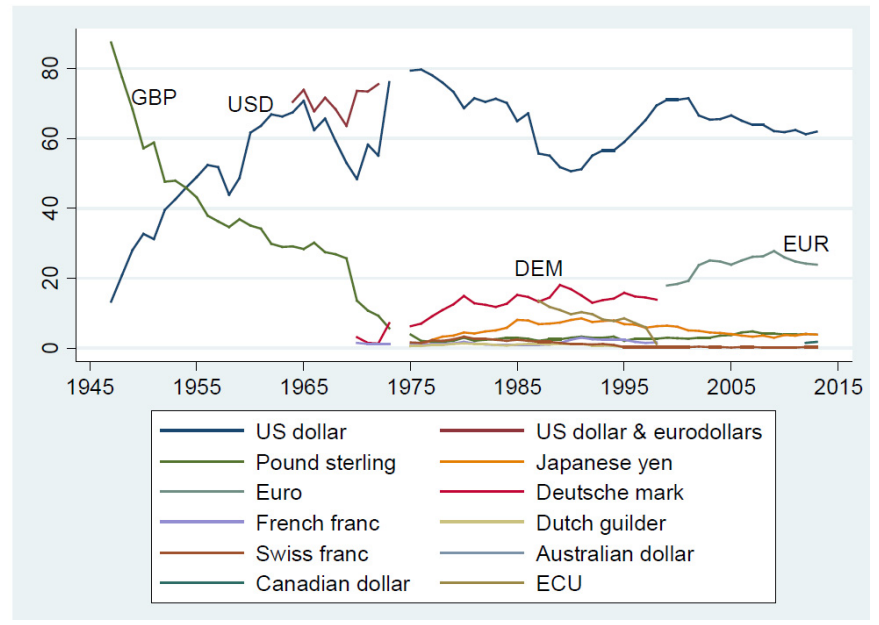

Source: Eichengreen, Chitu and Mehl (2014b)

13) Global subject to the caveat in footnote 5 above.

14) This is the case of Eurodollar assets, which are included along with U.S.-issued reserve assets denominated in dollars. 
Still, the dominance of sterling at the beginning of the period and the subsequent reversal of fortune are the figure's most striking features. The numerical dominance of sterling in 1947 reflected the willingness of the United Kingdom's wartime allies to accept sterling-denominated claims on the British government in payment for materiel and foodstuffs provided to the British economy and its armies overseas. Much of the sterling held in 1947 was accumulated because of these special wartime circumstances (details are in Schenk 2013). It followed that many of sterling's holders wished to transform it into other reserve assets, the dollar being the obvious alternative, and/or to use it to purchase merchandise (that is, to liquidate it entirely), which they did over time to the extent that such conversion and liquidation were permitted. Hence the reversal evident in Figure 10.

Figure 10 also points to the possibility of structural breaks in the determinants of the currency composition of foreign exchange holdings in the late 1960s or early 1970. The dollar's share stops rising in the late 1960s. This is when currencies other than sterling and the dollar (notably the deutschemark, but also others) make an appearance in central bank reserve portfolios. It is when serious doubts developed about the stability of the Bretton Woods gold-dollar system. Contemporaries speculated that there might be large scale portfolio rebalancing away from the dollar if the greenback lost its asymmetric role with the collapse of the Bretton Woods System (Frenkel 1980).

In fact, if one estimates equations designed to explain the currency composition of international reserves, following standard specifications in the literature which include as determinants issuing country size (as a measure of network effects), lagged currency shares (as a measure of inertia) and inflation and currency depreciation (as measures of policy credibility), the data (and associated Chow Tests) suggest that the break in the relationship occurred well before the breakdown of Bretton Woods, already in 1968 (when the gold pool designed to support the dollar peg to gold effectively collapsed).

At one level, not that much changes with this structural break. In particular, the big shift away from the dollar forecast by some contemporaries failed to materialize. At the same time, some changes are evident.15) A selection of these regressions, from Eichengreen, Chitu and Mehl (2014b), is shown in Table 1. 
Table 1. Regression Results, Periods Before and After 1973

\begin{tabular}{|c|c|c|c|c|}
\hline & $\begin{array}{l}\text { (1) } \\
\text { Full sample }\end{array}$ & $\begin{array}{c}(2) \\
\text { Pre-1973 }\end{array}$ & $\begin{array}{c}(3) \\
\text { Post-1973 }\end{array}$ & $\begin{array}{l}\text { (4) } \\
\text { Full sample }\end{array}$ \\
\hline Inetia & $\begin{array}{r}0.927^{* * *} \\
(0.021)\end{array}$ & $\begin{array}{r}0.758^{* * *} \\
(0.037)\end{array}$ & $\begin{array}{r}0.954^{* * *} \\
(0.009)\end{array}$ & $\begin{array}{r}0.886^{* * *} \\
(0.027)\end{array}$ \\
\hline Network effects & $\begin{array}{r}0.216^{* * *} \\
(0.066)\end{array}$ & $\begin{array}{r}0.815^{* * *} \\
(0.113)\end{array}$ & $\begin{array}{r}0.115^{* * *} \\
(0.024)\end{array}$ & $\begin{array}{r}0.426^{* * *} \\
(0.080)\end{array}$ \\
\hline Credibility & $\begin{array}{c}0.051^{* *} \\
(0.022)\end{array}$ & $\begin{array}{r}-0.599^{* * *} \\
(0.033)\end{array}$ & $\begin{array}{c}0.043^{*} \\
(0.024)\end{array}$ & $\begin{array}{r}-0.382^{* * *} \\
(0.092)\end{array}$ \\
\hline Post-73 dummy & & & & $\begin{array}{r}2.921^{* * *} \\
(0.943)\end{array}$ \\
\hline Inertia $\times$ post -73 dummy & & & & $\begin{array}{r}0.045^{* *} \\
(0.023)\end{array}$ \\
\hline Netowrk effects $\times$ post -73 dummy & & & & $\begin{array}{r}-0.242^{* * *} \\
(0.075)\end{array}$ \\
\hline Credibility $\times$ post -73 dummy & & & & $\begin{array}{r}0.428^{* * *} \\
(0.116)\end{array}$ \\
\hline Constant & $\begin{array}{l}-0.010 \\
(0.295)\end{array}$ & $\begin{array}{r}-5.725^{* * *} \\
(0.460)\end{array}$ & $\begin{array}{r}0.302 \\
(0.317)\end{array}$ & $\begin{array}{r}-2.739 * * \\
(1.095)\end{array}$ \\
\hline Currency effects & YES & YES & YES & YES \\
\hline Time effects & YES & YES & YES & YES \\
\hline Observations & 271 & 42 & 229 & 271 \\
\hline No. of groups & 8 & 4 & 8 & 8 \\
\hline$R^{2}$ (overall) & 0.993 & 0.988 & 0.995 & 0.993 \\
\hline
\end{tabular}

Robust standard errors in parentheses

*** $\mathrm{p}<0.01, * * p<0.05, * \mathrm{p}<0.1$

Source: Eichengreen, Chitu and Mehl (2014b)

There is evidence there that network effects grow weaker between the two periods, consistent with the "new view" of reserve currency competition. Inertia or persistence grows strong (perhaps reflecting habit formation, and perhaps reflecting the absence of viable alternatives to the dollar following sterling's decline). ${ }^{16)}$ Policy credibility, meanwhile, also becomes more important.

15) This table from Eichengreen, Chitu and Mehl (2014b) distinguishes pre- and post-1973 periods rather than before and after 1968, consistent with the earlier literature, but the same patterns carry over if instead we break the sample in the late 1960s.

16) This is as good a place as any to draw the distinction between network effects and persistence, and to emphasize that one does not imply the other. Persistence can have other sources besides network effects giving rise to first- mover advantage (habit formation, for example, or the absence of low-cost alternatives for providing reserves on the scale demanded). As David (1986, 1990) stresses, network 
The other clear implication of Figure 10 is how the absence of viable alternatives supported the continued dominance of the dollar in the second half of the 20th century. One can also see, from the sudden appearance of the light green line on the figure's right hand side, why the euro was seen as a potential challenger to the dollar's hegemony (as analyzed by Cohen 2012). Equally evident, however, is how the euro crisis represented a setback to the single European currency's global aspirations. The euro's share of identified global foreign exchange reserves peaked in 2009, on the eve of the crisis, and it's been down, down ever since. If Europe succeeds in drawing a line under its crisis, this trend may ultimately reverse. But whether or not this will be the case, only time will tell.

What does this history imply for the future? Strong persistence implies a continuing international currency role for the dollar, absent policy miss-steps that undermine U.S. policy credibility. The dollar's rapid rise to rival sterling in the 1920s reflected the combination of sharp negative shocks to the incumbent international currency (due to World War I) and far-reaching reform to enhance the attractions of the rival (first and foremost, passage of the Federal Reserve Act). The dollar's dominance after World War II similarly reflected a combination of negative shocks to its rival (due to World War II) and efforts on the part of U.S. policy makers to enhance the attractions of the greenback (inter alia, the Marshall Plan). Absent a similar combination of negative shocks affecting the reputation of the incumbent and positive steps to enhance the attractions of rivals, there is every reason to expect the dollar's international role to persist.

But the fact that network effects are not everything suggests that there is also a role for supplementary sources of international liquidity, for example China and the renminbi. This observation should be seen as reassuring, given the inability of the United States to continue to function as the sole supplier of international liquidity to a global economy that will presumably continue to expand more rapidly than the U.S. itself. And 1920s history suggests that new sources of liquidity

effects may increase the attractions of a particular standard (in this case, a currency standard) at a specific point in time without preventing market participants from shifting to another standard at the next point in time, assuming that lock-in mechanisms are weak and agents are able to coordinate their actions. The success with which open standards for personal electronics have been developed in recent years, weakening lock-in and facilitating shifts between operating systems, illustrates the point. 
can acquire a role quite rapidly (contrary to the "old view" of international currency competition). A number of recent studies have reached similar conclusions; thus, Lee (2014) estimates that the renminbi will account for 3 to 12 per cent of global foreign exchange reserves circa 2035, which will be significantly behind the dollar but still a consequential share.

China, admittedly, faces stiff challenges in seeking to elevate the renminbi to first-class international currency status. An international currency has three essential attributes: size, stability and liquidity. The dollar was able to quickly assume an international role in the 1920s because the U.S. had the size (U.S. financial markets already being bigger than British financial markets), the stability (experiencing no financial crises between 1915 and 1929 - and what occurred thereafter can be considered proof through counter-example) and the liquidity (having established a central bank to backstop domestic financial markets and provide liquidity to the market in dollar-denominated trade credits). ${ }^{17)}$ Chinese financial markets, to put the matter bluntly, still lack the requisite size, stability and liquidity, attributes that the country will have to work hard to develop (for further discussion see Gagnon and Troutman 2014).

Finally, one can ask whether China's politics are compatible with its international monetary ambitions. All reserve currencies in history have been the currencies of republics or political democracies. Both Britain and the U.S. had contested elections and political systems that limited arbitrary executive action. This was important for fostering confidence on the part of both domestic and foreign investors. Republican forms of government had similar effects in the Dutch Republic and the city-states of Genoa and Venice, three earlier issuers of what arguably functioned as international currencies.

Freely contested elections and even limits on the exercise of power by the executive are not exactly characteristics of China's political system. But might China be able to establish limits on arbitrary executive action within the context of its prevailing political system? Perhaps. Even today, the general secretary of the

17) On the magnitude of U.S. financial markets in the 19th century and after, see Rousseau and Sylla (1999), and on the role of the Fed in providing liquidity to the market in trade credits, or trade acceptances, see Eichengreen (2011). 
Communist Party is increasingly constrained by the National People's Congress and the diverse interests represented there. Other bureaucratic decision makers are increasingly constrained by requirements of transparency and disclosure. Popular internet-based movements are forcing Chinese policy makers to strengthen labor and environmental standards; why not also creditor rights, one might ask? One can imagine giving key monetary policy makers (the People's Bank of China) statutory independence from politics - a reasonably independent central bank plausibly being a prerequisite in order for foreign investors, including foreign central banks and governments, to vest confidence in a currency.

Will such changes be compatible with China's prevailing political system? Will they be enough? Only time will tell. These are not questions to which history offers clear answers. 


\section{References}

Arthur, B. (1989), "Competing Technologies, Increasing Returns, and Lock-In by Historical Events," Economic Journal, Vol. 99, pp. 116-131.

Bensassy, Q., Agnes, and J. Pisani-Ferry (2011), "The Long March Towards a Multi-Polar Monetary Regime,” Lettre du CEPII 308, Paris:CEPII [gradual transition is in the cards]

Borio, C., and P. Disyatat (2011), "Global Imbalances and the Financial Crisis: Link or No Link?” BIS Working Paper No. 346.

Chinn, M., and J. Frankel (2005), "Will the Euro Eventually Surpass the Dollar as Leading International Reserve Currency?” NBER Working Paper No. 11510.

Chitu, L., B. Eichengreen, and A, Mehl (2012), "When Did the Dollar Overtake Sterling as the Leading International Currency? Evidence from the Bond Markets,” ECB Working Paper No. 1433.

Clark, D. (2003), “The Design of Open Systems," IEEE Internet Computing 7, pp. $86-95$.

Cohen, B. (2012), "The Future of Global Currency: The Euro versus the Dollar," London: Routledge.

Cohen, B. (2013), "Currency and State Power," in Martha Finnimore and Judith Goldstein eds., Back to Basics: State Power in a Contemporary World, New York: Oxford University Press, pp. 159-176.

Cohen, B., and T. Benney (2013), "What Does the International Currency System Really Look like?” Review of International Political Economy, pp. 2-25.

David, P. (1986), "Narrow Windows, Blind Giants and Angry Orphans: The Dynamics of Systems Rivalries and dilemmas of Technology Policy," Technology Innovation Project Working Paper no.10, Center for Economic Policy Research, Stanford University.

David, P. (1990), “The Economics of Compatibility Standards: An Introduction to Recent Research,” Economics of Innovation and New Technology 1, pp. 3-41.

David, P., and J. Bunn (1988), "The Economics of Gateway Technologies and Network Evolution: Lessons from Electricity Supply History," Information Economics and Policy 3, pp. 165-202. 
De Cecco, M. (1974), "Money and Empire: The International Gold Standard," Oxford: Blackwell, pp. 1890-1914.

De Cecco, M. (2009), "From Monopoly to Oligopoly: Lessons from the Pre-1914 Experience," in Eric Helleiner and Jonathan Kirschner eds., The Future of the Dollar, Ithaca, NY: Cornell University Press.

Decorzant, Y., and J. Flores (2012), "Public Borrowing in Harsh Times: The League of Nations Loans Revisited," Working Paper in Economic History No.12-07, University Carlos III de Madrid.

Eichengreen, B. (2011), Exorbitant Privilege: The Rise and Fall of the Dollar and the Future of the International Monetary System, New York: Oxford University Press.

Eichengreen, B. (2013a), "Currency War or International Policy Coordination?" Journal of Policy Modeling; Vol. 35, pp. 425-433.

Eichengreen, B. (2013b), "Renminbi Internationalization: Tempest in a Teapot?" Asian Development Review, Vol. 30, pp. 148-164.

Eichengreen, B., L. Chitu, and A. Mehl (2014a), "Network Effects, Homogeneous Goods and International Currency Choice: New Evidence on Oil Markets from an Older Era," ECB Working Paper No. 1651.

Eichengreen, B., L. Chitu, and A. Mehl (2014b), "Stability or Upheaval? The Currency Composition of International Reserves in the Long Run," unpublished manuscript, University of California, Berkeley and European Central Bank .

Eichengreen, B., and M. Flandreau (2009), "The Rise and Fall of the Dollar (or When Did the Dollar Replace Sterling as the Leading International Currency?)," European Review of Economic History, Vol. 13, pp. 377-413.

Eichengreen, B., and M. Flandreau (2012), "The Federal Reserve, the Bank of England and the Rise of the Dollar as an International Currency, 1914-1939," Open Economies Review, Vol. 23, pp. 57-87.

Eichengreen, B., and M. Flandreau (2014), "A Century and a Half of Central Banks, International Reserves and International Currencies," unpublished manuscript, University of California, Berkeley and Graduate Institute, Geneva, forthcoming in the anniversary volume of the Bank of Norway. 
European Cooperation Administration (1949), "Petroleum and Petroleum Equipment Commodity Study," European Recovery Program, Washington, DC: ECA.

Farrell, J., and P. Klemperer (2007), "Coordination and Lock-In: Competition with Switching Costs and Network Effects," Handbook of Industrial Organization, Vol. 3, pp. 1967-2082,

Flandreau, M., and C. Jobst (2009), "The Empirics of International Currencies: Network Externalities, History and Persistence," Economic Journal, Vol. 119, pp. 643-664.

Flandreau, M., and S. Ugolini (2013), "Where it All Began: Lending of Last Resort and Bank of England Monitoring during the Overend, Gurney Panic of 1866," in Michael D. Bordo, and William Roberds (eds), The Origins, History, and Future of the Federal Reserve: A Return to Jekyll Island, Cambridge: Cambridge University Press.

Frankel, J. (2011), "Historical Precedents for the Internationalization of the RMB," paper written for a workshop organized by the Council of Foreign Relations and the China Development Research Foundation.

Frenkel, J. (1980), “The Demand for International Reserves Under Pegged and Flexible Exchange Rate Regimes," in David Bigman an Teizo Taya eds., The Functioning of Floating Exchange Rates: Theory, Evidence and Policy Implications, Cambridge, Mass.: Ballinger, pp. 169-195.

Gagnon, J., and K. Troutman (2014), "Internationalization of the Renminbi: The Role of Trade Settlement," Policy Brief PB 14-15, Washington, D.C.: Peterson Institute of International Economics.

Gilbert, M. (1968), "The Gold-Dollar System: Conditions of Equilibrium and the Price of Gold," Essays in International Finance, No.70, International Finance Section, Department of Economics, Princeton University.

James, H. (2009a), "The Enduring Preeminence of the Dollar," in Eric Helleiner and Jonathan Kirschner eds., The Future of the Dollar, Ithaca, NY: Cornell University Press.

James, H. (2009b), "Economic Crisis and Regional Integration," Project Syndicate (4th March), www.projectsyndicate.com.

Horsefield, K. (1969), “The International Monetary Fund 1945-1965: Twenty 
Years of International Monetary Cooperation: Chronicle," Washington, D.C.: IMF.

Keynes, J. M. (1930), “A Treatise on Money,” London: Macmillan [two volumes]. Kindleberger, C. (1973), "The World in Depression, 1929-1939," Berkeley: University of California Press.

Kindleberger, C. (1988), "The International Economic Order: Essays on Financial Crisis and International Public Goods," Cambridge, Mass.: MIT Press.

Krugman, P. (1980), "Vehicle Currencies and the Structure of International Exchange," Journal of Money, Credit and Banking; Vol. 12, pp. 513-526.

Krugman, P. (1984), "The International Role of the Dollar: Theory and Prospect," in John Bilson and Richard Marston (eds), Exchange Rate Theory and Practice, Chicago: University of Chicago Press, pp. 261-278.

Kwan, C.H. (2012), "Japan's Experience with Promoting the Yen as an International Currency: Lessons for China," unpublished manuscript, Nomura (February).

League of Nations (1937), "Monetary Review," Geneva: League of Nations.

Lee, J. W. (2014), "Will the Renminbi Emerge as an International Reserve Currency?" World Economy, Vol. 37, pp. 42-62.

Liebowitz, S., and S. Margolis (1995), "Path Dependence, Lock-In and History," Journal of Law, Economics and Organization, Vol. 11, pp. 205-226.

Lindert, P.r (1969), "Key Currencies and Gold, 1900-1913," Princeton Studies in International Finance, No.24, International Finance Section, Department of Economics, Princeton University.

Maddison, A. (1982), "Phases of Capitalist Development," New York: Oxford University Press.

McKinnon, R. (1996), The Rules of the Game: International Money and Exchange Rates, Cambridge, Mass.: MIT Press.

McKinnon, R. (2010), "Rehabilitating the Unloved Dollar Standard," Asian-Pacific Economic Literature, Canberra: Crawford School of Economics and Government, the Australian National University.

Matsuyama, K., N. Kiyotaki, and A. Matsui (1993), "Toward a Theory of International Currency," Review of Economic Studies, Vol. 60, pp. 283-30.

Nurkse, R. (1944), “International Currency Experience,” Geneva: League of Nations. 
Obstfeld, M., and K. Rogoff (2011), "Global Imbalances and the Financial Crisis: Products of Common Causes," in Reuven Glick and Mark Spiegel (eds), Asia and the Global Financial Crisis, San Francisco: Federal Reserve Bank of San Francisco, pp. 131-172.

Obstfeld, M., and A. Taylor (2005), Global Capital Markets: Integration, Crisis and Growth, Cambridge: Cambridge University Press.

Park, Y. C., and C.Y. Song (2011), "Renminbi Internationalization: Prospects and Implications for Economic Integration in Asia," Asian Economic Papers, Vol. 10, pp. 42-72.

Portes, R., and H. Rey (1998), "The Emergence of the Euro as an International Currency", Economic Policy, pp. 307-343.

Prasad, E. (2014), "The Dollar Trap: How the U.S. Dollar Tightened its Grip on Global Finance,” Princeton: Princeton University Press.

Rey, H. (2001), "International Trade and Currency Exchange," Review of Economic Studies, Vol. 68, pp. 443-464.

Rousseau, P., and R. Sylla (1999), "Emerging Financial Markets and Early U.S. Growth," NBER Working Paper No. 7448.

Schenk, C. (2013), "The Decline of Sterling: Managing the Retreat of an International Currency, 1945-1992," Cambridge: Cambridge University Press.

Strange, S. (1971), "The Politics of International Currencies," World Politics, Vol. 23, pp. 213-231.

Subramanian, A. (2011), "Eclipse: Living in the Shadow of China's Economic Dominance," Washington, D.C.: Peterson Institute of International Economics. Subramanian, A., and M. Kessler (2013), "The Renminbi Bloc is Here: Asia Down, Rest of the World to Go?" Working Paper No. 12-19, Washington, D.C.: Peterson Institute of International Economics, Revised(August).

Triffin, R. (1960), "Gold and the Dollar Crisis,” New Haven: Yale University Press. Whelan, K. (2010), "Global Imbalances and the Financial Crisis," Working Paper No.10-13, University of Dublin, School of Economics (April).

Williamson, J. (2012), "Currencies of Power and the Power of Currencies: The Geo-Politics of Currencies, Reserves and the Global Financial System,” Unpublished manuscript, International Institute for Strategic Studies, Washington, D.C. 


\section{<Abstract in Korean>}

Barry Eichengreen*

네트워크의 외부성으로 인해 궁극적으로 하나의 통화만이 국제통화로 남게 된다는 'old view'와 현실에서는 다수의 국제 통화들이 공존하는 상황이 발생해 전환비용이 크지 않다는 'new view' 가 있다.

'new view'의 입장에서 국가의 통화들을 정리하고-가장 근접하게는 미국 달 러나 중국의 렌민비가-멀지 않은 미래에 이 국제 통화 역할을 공유할 가능성이 있음을 시사한다.

* Professor, University of California, Berkeley 